\title{
O agronegócio brasileiro e as negociações Mercosul-União Europeia ${ }^{1}$
}

\author{
Brazilian agribusiness and \\ Mercosur-European Union negotiations
}

DOI: $10.21530 /$ ci.v14n3.2019.940

Roberta Rodrigues Marques da Silva²

Ricardo Dias da Silva ${ }^{3}$

Fernanda Ramos Ferreira ${ }^{4}$

\section{Resumo}

Este artigo objetiva analisar as negociações entre Mercosul e União Europeia, especialmente no que diz respeito à posição brasileira nas tratativas conduzidas durante os governos Dilma Rousseff e Michel Temer, enfatizando a coordenação do agronegócio em torno da agenda de discussão. Observamos que as negociações entre os dois blocos permaneceram como prioridade da política externa brasileira, a despeito das diferenças programáticas fundamentais entre os dois governos. Para explicar a permanência das negociações, além do impasse em torno do fechamento do acordo, argumentamos que a mudança estrutural na economia brasileira, marcada pela desindustrialização progressiva e pela reprimarização da pauta exportadora, lado a lado à maior capacidade de coordenação da ação coletiva do agronegócio, produziram impactos na formatação dos interesses brasileiros durante as negociações. Buscamos trazer evidências para corroborar nossa hipótese, analisando as tratativas no período recente. Observamos que itens caros à indústria foram flexibilizados, ao passo que foi mantida a defesa de maior acesso aos mercados agropecuários europeus, item considerado inegociável pela UE.

Palavras-chave: Mercosul; União Europeia; Agronegócio; Economia Política.

1 O artigo inclui os resultados da pesquisa "As negociações comerciais internacionais do Brasil no século XXI”, que contou com apoio da FAPERJ por meio da concessão de bolsa de iniciação científica.

2 Professora Adjunta do Departamento de Ciência Política da Universidade Federal Fluminense. Doutora em Ciência Política pelo Instituto de Estudos Sociais e Políticos da Universidade do Estado do Rio de Janeiro.

3 Pós-Doutor e Doutor em Ciências Sociais em Desenvolvimento, Agricultura e Sociedade pela Universidade Federal Rural do Rio de Janeiro.

4 Graduanda em Relações Internacionais pela Universidade do Estado do Rio de Janeiro. Foi bolsista de iniciação científica pela Faperj entre 2016 e 2018, no projeto “As negociações comerciais internacionais do Brasil no século XXI”, coordenado pela professora Roberta Rodrigues Marques da Silva.

Artigo submetido em 14/04/2019 e aprovado em 23/09/2019. 


\begin{abstract}
The paper aims to analyze the negotiations between Mercosur and the European Union, emphasizing the Brazilian position during Dilma Rousseff and Michel Temer administrations. We highlight the coordination of agribusiness regarding trade policy. We observe that the negotiations between the two blocs remained a priority of Brazilian foreign policy, despite the fundamental programmatic differences between Rousseff and Temer. To explain the continuity of the negotiations and the impasse surrounding the closure of the agreement, we argue that the structural change in the Brazilian economy, marked by progressive deindustrialization and reprimarization of exports, along with the greater coordination capacity of agribusiness collective action, produced impacts on the formation of Brazilian interests during the negotiations. We bring evidence to corroborate our hypothesis, analyzing the negotiations in the recent period. We note that items dear to the industry sector were relaxed, while the defense of greater access to European agricultural markets was kept, an item considered non-negotiable by the EU.
\end{abstract}

Keywords: Mercosur; European Union; Agribusiness; Political Economy.

\title{
Introdução
}

A ruptura política que levou à emergência de Michel Temer ao poder (20162018), em substituição à presidente deposta Dilma Rousseff (2011-2016), conduziu a inflexões também na política externa brasileira, que abandonou a ênfase em uma perspectiva política da inserção internacional do país em favor da retomada da perspectiva comercialista, prevalecente na década de 1990. Os novos rumos definidos para a política externa acompanhavam a mudança na política econômica, que passou a se orientar pela promoção de reformas estruturais, marcadas pela redução da presença do Estado na economia.

Nesse contexto, é emblemática a permanência da ênfase conferida pela chancelaria brasileira às negociações entre o Mercado Comum do Sul (Mercosul ) e a União Europeia (UE) em torno da assinatura de um acordo de livre comércio, concluído em junho de 2019, nos primeiros meses do governo Jair Bolsonaro5. Ademais, também se destaca a prioridade dada ao agronegócio nas transações, não obstante a permanência de certos interesses defensivos do setor industrial na definição da posição negociadora brasileira. Neste artigo, nos debruçamos

5 O escopo da pesquisa cujos resultados são apresentados neste artigo não abarcou a análise do governo Jair Bolsonaro. Assim, a análise da conclusão das tratativas e assinatura do acordo deverá ser objeto de pesquisas futuras. Vale destacar que ainda está pendente a ratificação do acordo pelos países que compõem os blocos. 
sobre as negociações Mercosul-UE, especialmente no que diz respeito à posição brasileira nas tratativas conduzidas durante os governos Dilma Rousseff e Michel Temer, enfatizando a coordenação da ação do agronegócio em torno da agenda de discussão. Não parece plausível supor que a explicação para a continuidade nas negociações Mercosul-UE resida nas orientações mais gerais da política externa brasileira $^{6}$. A explicação deve ser buscada, ao nosso ver, nos alinhamentos dos grupos socioeconômicos no nível doméstico.

Desde a década de 1980, observa-se uma mudança estrutural na economia brasileira, com o avanço da desindustrialização (SARTI; HIRATUKA, 2018) e, paralelamente, o aumento significativo da participação de commodities agrícolas, energéticas e minerais na pauta exportadora, ou reprimarização das exportações (DELGADO, 2010; SALAMA, 2016). Esse duplo processo, iniciado durante a chamada “década perdida”, e que ganhou maior intensidade a partir da abertura comercial durante o governo Fernando Collor (1990-1992) (SARTI; HIRATUKA, 2018), acentuou-se na década de 2000 em razão do aumento expressivo dos preços das commodities no mercado internacional, o que ficou conhecido como o boom das commodities (DELGADO, 2010). Sustentamos a hipótese de que à expansão da participação do setor primário no PIB e nas exportações, seguiu-se a coordenação dos atores do agronegócio em torno do estabelecimento de posições comuns em matéria de inserção internacional, incluindo aí a busca por influenciar a posição negociadora brasileira em negociações comerciais, de modo que seus interesses fossem contemplados. A convergência, que teve início na época das negociações em torno da Área de Livre Comércio das Américas (ALCA), avançou ao longo das tratativas entre Mercosul e União Europeia. Isso explicaria a continuidade do protagonismo das negociações Mercosul-UE na agenda da política externa brasileira, bem como as mudanças no conteúdo da posição negociadora brasileira, com progressivo avanço relativo dos interesses do agronegócio. Embora não seja possível estabelecer uma relação causal entre as variáveis presentes na nossa hipótese, consideramos razoável afirmar que há uma interrelação entre elas.

Há uma importante literatura que trata da formação da posição negociadora brasileira em transações comerciais internacionais, de modo geral (CARVALHO, 2003; CARVALHO, 2010; IGLÉCIAS, 2007), e nas negociações Mercosul-UE, em particular (BEZERRA, 2008; SANTOS, 2018), com atenção aos interesses dos grupos econômicos domésticos. No entanto, pouco se tem discutido sobre a importância crescente do agronegócio nessas negociações. Neste artigo, pretendemos cobrir parte desta lacuna.

6 E também da política externa argentina desde o governo Mauricio Macri, de orientação neoliberal. 
Para tanto, empregamos um método de análise qualitativo, que busca estabelecer a interrelação entre restrições estruturais - seja oriundas do contexto internacional, seja emanadas da economia política doméstica - e a agência, isto é, a organização dos interesses do agronegócio brasileiro no que diz respeito à política comercial, especialmente as negociações Mercosul-UE. Recorremos à revisão bibliográfica e documental, além da consulta a jornais, em especial ao Valor Econômico, para levantarmos as informações sobre as negociações então em curso.

No que segue, o artigo se organiza da seguinte forma: na primeira seção, discutimos as mudanças na formulação da política econômica externa brasileira nas últimas décadas, tendo em vista os realinhamentos internos e as principais mudanças na conjuntura internacional. Na sequência, nosso foco recai sobre o encaminhamento das negociações entre Mercosul e UE nos governos Fernando Henrique Cardoso e Lula, enfatizando o avanço na coordenação da ação do agronegócio. Na terceira seção, discutimos a posição do Brasil nas negociações entre os dois blocos durante os governos Dilma e Temer, trazendo evidências da importância crescente dos interesses do agronegócio no conjunto das reivindicações brasileiras. As conclusões encerram o artigo.

\section{A economia política da política econômica externa brasileira}

As negociações Mercosul-UE tiveram início em 1999 e foram concluídas vinte anos depois, em junho de 2019. Apesar do impasse de longa-data, marcado por interrupções e retomadas nas negociações, é surpreendente que as tratativas tenham se mantido na agenda, a despeito das mudanças de governo experimentadas nos países que compõem os blocos em tela. No caso do Mercosul, em especial, as negociações tiveram início no marco de governos de orientação neoliberal prosseguiram durante os governos da virada à esquerda ${ }^{8}$ e se mantiveram como pauta prioritária após o retorno de presidentes de direita ao poder ${ }^{9}$. Não é demais lembrar que a resistência da Venezuela, governada por Hugo Chávez, e dos países do Mercosul ${ }^{10}$, especialmente Brasil, sob a presidência de Lula, e Argentina, na

7 Fernando Henrique Cardoso (Brasil), Fernando de la Rúa, (Argentina), Julio María Sanguinetti (Uruguai). Luis Ángel González Macchi era o presidente provisório do Paraguai.

8 Luiz Inácio Lula da Silva e Dilma Rousseff (Brasil), Néstor Kirchner e Cristina Fernández de Kirchner (Argentina), Tabaré Vázquez e José Mujica (Uruguai) e Fernando Lugo (Paraguai).

9 Michel Temer e Jair Bolsonaro (Brasil), Mauricio Macri (Argentina), Federico Franco, Horácio Cartes e Mario Benítez (Paraguai). Apenas o Uruguai mantém um governo de centro-esquerda, de Tabaré Vázquez. A Venezuela, governada por Nicolás Maduro, foi suspensa do Mercosul e não chegou a participar das negociações com a UE.

10 A Venezuela não era, então, membro do bloco. 
administração de Néstor Kirchner, contribuiu para enterrar as negociações em torno da ALCA, em 2005 (MENEZES, 2011), o que não aconteceu no caso das negociações com a UE.

Para além das alterações de governo, também surpreende a manutenção das negociações entre o Mercosul e a UE, apesar das mudanças significativas no contexto das relações comerciais internacionais desde a década de 1990. As negociações entre os dois blocos econômicos tiveram início em um momento em que eram altas as expectativas em torno das negociações na Organização Mundial do Comércio (OMC), criada em 1995 a fim de estabelecer um aparato regulatório em prol da liberalização do comércio internacional ${ }^{11}$. Esse ambiente favorável à liberalização comercial era replicado também no nível regional, com a proliferação de blocos econômicos - entre os quais o próprio Mercosul, criado em $1991^{12}$ - , o que trazia prognósticos promissores em torno da possibilidade de estabelecimento de um acordo de livre comércio entre Mercosul e UE.

Como é sabido, as negociações no âmbito da Rodada Doha da OMC chegaram a um impasse na Conferência de Cancún, em 2003, quando os países em desenvolvimento, liderados por Brasil e Índia, articularam suas ações no âmbito do G-20, posicionando-se contrariamente à proposta de agenda dos países desenvolvidos Estados Unidos e UE - que privilegiavam negociações em torno do maior acesso aos mercados de serviços (inclusive financeiros), regulação dos investimentos e das compras governamentais, concorrência e facilitação do comércio. Para o Brasil, os países desenvolvidos deveriam apresentar como contrapartida uma proposta de redução dos subsídios pagos aos seus agricultores, o que permitiria maior acesso aos seus mercados pelos produtores dos países agroexportadores. Índia e Argentina, por outro lado, possuíam diferenças mais fundamentais em relação à Rodada Doha, demandando, respectivamente, o estabelecimento de salvaguardas agrícolas e medidas de proteção à indústria nacional.

As diferenças entre a posição brasileira e a dos seus principais parceiros no G-20 e no Mercosul se tornaram patentes em 2008, quando o Brasil, lado a lado com Estados Unidos e UE, apoiou a proposta apresentada por Pascal Lamy, então Diretor Geral da OMC, para o destravamento das negociações, a qual foi rejeitada por Índia e Argentina e não saiu do papel. Em linhas gerais, a proposta previa a redução dos subsídios pagos pelos países desenvolvidos aos seus produtores agrícolas, em troca da redução das tarifas de importação de bens industrializados.

11 A OMC albergou e ampliou o escopo do acordo sobre comércio de bens estabelecido no âmbito do GATT, além de regular o comércio de serviços e propriedade intelectual.

12 Estabelecido como Área de Livre Comércio em 1991 e convertido em união aduaneira em 1994. 
Trata-se de um episódio relevante para a compreensão da posição negociadora do Brasil em temas comerciais - seja no nível multilateral, seja no âmbito regional -, que evidencia a preponderância dos interesses ofensivos do agronegócio sobre os interesses defensivos da indústria.

O maior protagonismo dos interesses do agronegócio na formação da posição negociadora do Brasil também é visível nas tratativas Mercosul-UE. Isso não significa, porém, que os interesses do empresariado industrial sejam ignorados, haja vista que a proteção de setores específicos da indústria nacional permaneceu como item de dissenso nas negociações.

Como posto na introdução, a indústria experimentou redução significativa na sua participação no PIB e na pauta exportadora, o que pode nos ajudar a entender porque os seus interesses têm perdido a centralidade outrora obtida nas negociações internacionais das quais o Brasil faz parte. Os gráficos abaixo mostram a mudança estrutural experimentada pela economia brasileira nas últimas décadas, com a desindustrialização do país ${ }^{13}$ e a retração da participação das manufaturas na sua pauta exportadora, substituídas pelo aumento nas exportações de commodities.

Gráfico 1 - Brasil - Participação da indústria no PIB 1960-2017 (\%)

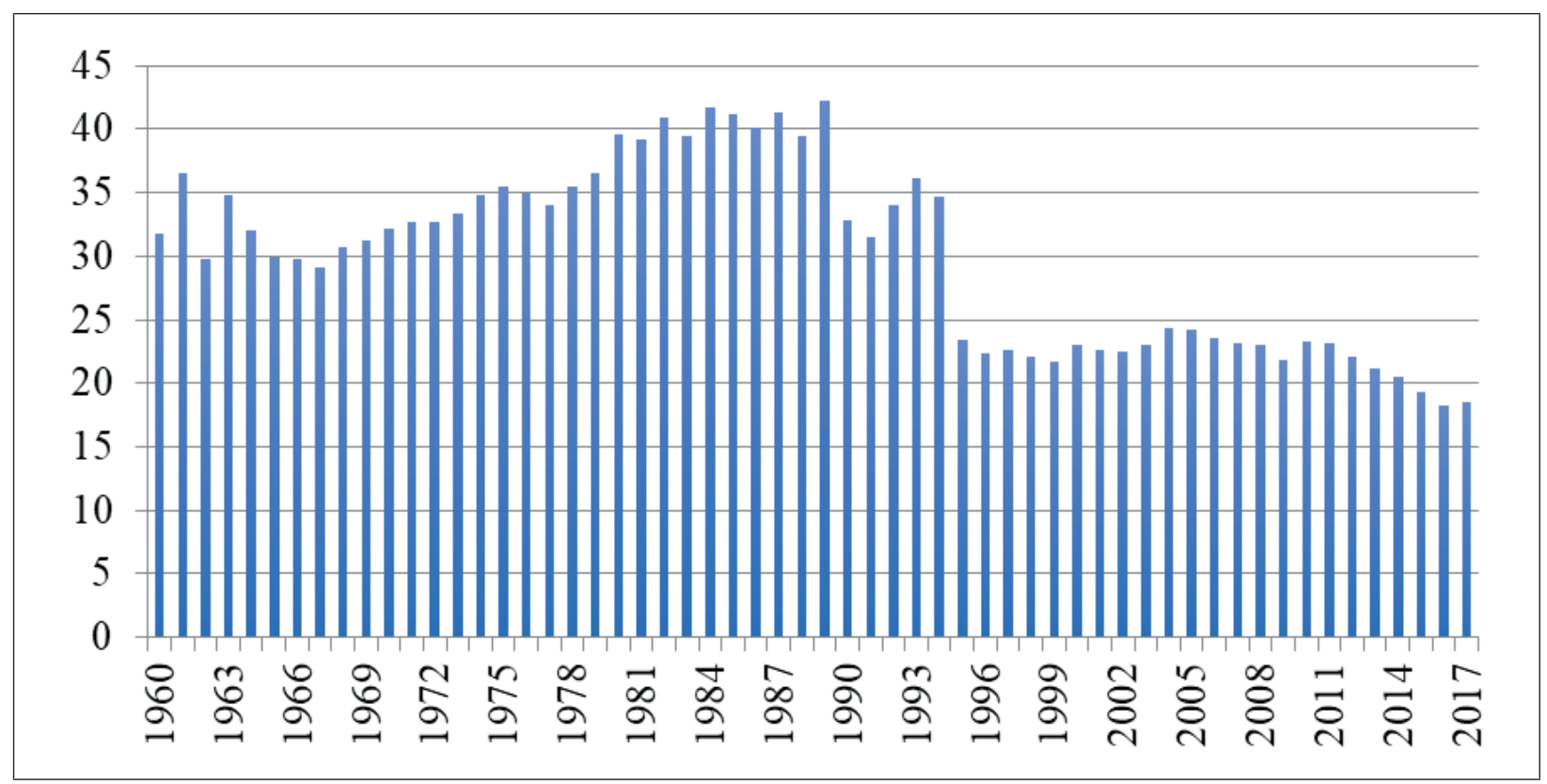

Fonte: Banco Mundial (2018).

13 Vale destacar que a indústria brasileira tem perdido participação relativa no PIB frente, não apenas ao setor primário, mas, também, ao setor de serviços, tendência igualmente observada nos países desenvolvidos. No entanto, conforme pontua Salama (2016, p. 131), a retração da participação da indústria no PIB e, mais importante, da indústria doméstica na indústria mundial começou a ser registrada no Brasil e nos demais países da América Latina quando estes possuíam renda per capita correspondente a apenas metade daquela registrada pelos países desenvolvidos quando o mesmo fenômeno passou a ser observado. 
Gráfico 2 - Brasil - Participação das manufaturas nas exportações - 1962-2016 (\%)

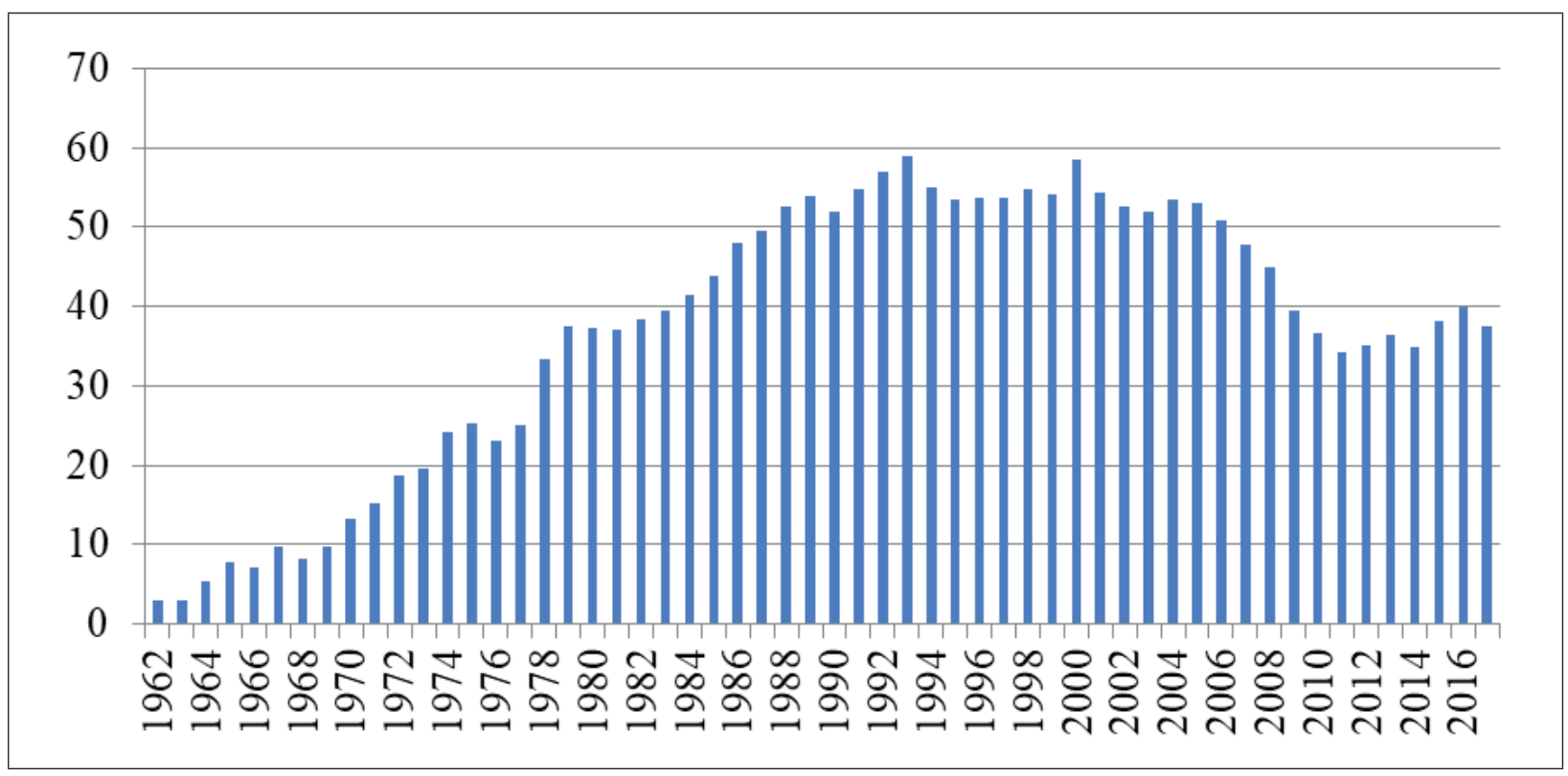

Fonte: Banco Mundial (2018).

Argumentamos que essa mudança estrutural tem impacto central no conflito distributivo, na medida em que o agronegócio passa a ocupar o espaço anteriormente pertencente ao empresariado industrial, principalmente no que diz respeito à sua participação nas exportações brasileiras.

Para além dessas profundas mudanças, é necessário destacar as alterações no contexto internacional nos anos recentes. Durante o governo Barack Obama, os Estados Unidos passaram a adotar uma estratégia de esvaziamento da OMC, privilegiando negociações em torno dos chamados mega-acordos regionais, como a Parceria Transpacífico (TPP, sigla em inglês), com países da Ásia, Oceania e América Latina, e a Parceria Transatlântica de Comércio e Investimento (TTIP, sigla em inglês) ${ }^{14}$, com a UE. Na administração seguinte, de Donald Trump, houve uma mudança radical em relação ao governo anterior, com a retirada dos Estados Unidos do TPP e uma posição errática com respeito ao TTIP, marcando a defesa do maior protecionismo econômico. Não obstante as diferenças fundamentais entre os governos Obama e Trump, é importante salientar que ambos rejeitaram a OMC como locus principal para as negociações comerciais internacionais. Além disso, tem se observado maior protagonismo da China no comércio e nos investimentos internacionais. Embora a China faça parte da OMC desde 2001, seu governo confere ênfase a negociações comerciais de caráter bilateral. O esvaziamento da arena multilateral impôs desafios à estratégia brasileira, que havia privilegiado 
as negociações no âmbito da OMC desde a sua criação, e com particular ênfase durante o governo Lula. Nesse contexto, a tentativa de chegar a um acordo entre Mercosul e UE acabou por se apresentar como alternativa viável para a inserção assertiva das exportações brasileiras no comércio internacional.

Ainda no plano internacional, o cenário econômico negativo, embora tenha tido início com a crise financeira de 2008, passou a impactar o Brasil com maior intensidade após 2010, isto é, já durante o governo Rousseff. Nesse período, observou-se o fim do chamado boom das commodities, com impacto significativo sobre as exportações brasileiras e sobre a arrecadação fiscal. Outra mudança relevante foi a acentuada expansão monetária nos países centrais, que levou à desvalorização das suas moedas e o impulso às suas exportações. Para o governo brasileiro, tratava-se de uma guerra cambial promovida pelos países desenvolvidos como saída unilateral da crise, que colocava o ônus sobre os países em desenvolvimento (MOROSINI; CORNETET, 2013; BASTOS; HIRATUKA, 2017).

No âmbito doméstico, o governo Rousseff, diferentemente do governo Lula, foi marcado no seu primeiro mandato pela confrontação em relação aos interesses rentistas ${ }^{15}$ e por maior intervencionismo estatal na economia, na busca por estabelecer uma agenda desenvolvimentista que reunisse os interesses do empresariado industrial e dos trabalhadores. O fracasso do "ensaio desenvolvimentista" se expressou na dupla crise - econômica e política - que levou o país à recessão e culminou na deposição da presidente. Vale salientar que o processo de impeachment foi apoiado pelo grande capital - bancos, agronegócio e empresariado industrial (SINGER, 2016).

Durante o "ensaio desenvolvimentista”, Rousseff priorizou uma estratégia que visava recuperar o papel da indústria na economia nacional, sem perder de vista os interesses do agronegócio. Impulsionar os interesses desses setores se tornava primordial também na política econômica externa. Nesse contexto, as negociações Mercosul-UE tornaram-se prioritárias, trazendo para o plano das relações inter-blocos temas que vinham sendo abordados, até então, durante as negociações fracassadas no plano multilateral. Rousseff visava conciliar os interesses do empresariado e do agronegócio a partir da adoção de políticas industriais no plano doméstico, ao mesmo tempo em que barganhava a abertura dos mercados europeus aos produtos agrícolas.

15 Por meio da redução dos juros e dos spreads bancários. 
Assim, muito embora tenha havido uma mudança radical entre o "ensaio desenvolvimentista" de Rousseff e a perspectiva neoliberal encampada pela Uma Ponte para o Futuro de seu sucessor, Temer ${ }^{16}$, é possível compreender a manutenção da priorização das negociações Mercosul-UE à luz da formatação da coalizão que concedeu apoio ao seu governo. Temer foi alçado ao poder com a já mencionada aproximação dos setores do grande capital nacional, e buscou adotar políticas mais ou menos próximas aos seus interesses ${ }^{17}$.

Também no âmbito da política econômica externa, os interesses destes grupos foram privilegiados, ainda que a ênfase recaia sobre as demandas do agronegócio. José Serra e Aloysio Nunes, ministros das Relações Exteriores durante o governo Temer, assumiram como prioridade da política externa a retomada das relações preferenciais com os países desenvolvidos, em particular no que diz respeito à assinatura de tratados de livre comércio. Em linhas gerais, foi estabelecida a busca pelo retorno do eixo bilateral da política externa, característica da década de 1990 (PECEQUILLO, 2008). No entanto, as condições de operação dessa estratégia são radicalmente diferentes daquelas prevalecentes até então: o contexto internacional passou a ser marcado pelo maior protecionismo por parte dos países desenvolvidos e pela ascensão da China. Nesse sentido, tornou-se mais difícil viabilizar a assinatura de acordos de livre comércio nos planos regional e multilateral, nos moldes da década de 90. Neste particular, a saída apresentada pelo governo Temer foi apostar nas difíceis negociações entre o Mercosul e a UE, tendo ao seu lado o apoio do presidente argentino Macri, com quem compartilhava ideias econômicas neoliberais.

Nesta seção, buscamos elucidar a interrelação entre as mudanças nos âmbitos internacional e doméstico e seus impactos sobre a definição da política econômica externa. A chave do nosso argumento, aqui apresentado, é que os governos buscam responder às restrições estruturais impostas pelas mudanças no perfil do setor produtivo e no contexto internacional. Na próxima seção, voltamonos para a segunda parte do nosso argumento, que repousa sobre a agência do agronegócio na defesa dos seus interesses em matérias de política comercial. Para

16 Não ignoramos, é claro, o giro em $180^{\circ}$ da política econômica de Rousseff adotado logo após a sua reeleição, em 2014, simbolizada pela escolha de Joaquim Levy para o Ministério da Fazenda, que culminou em políticas de ajuste fiscal.

17 Por exemplo: o congelamento dos gastos públicos, a paralisia dos assentamentos rurais, das demarcações de terras indígenas e o perdão das dívidas ruralistas - o que atende aos interesses do agronegócio -; a aprovação da contrarreforma trabalhista - que reduzia os custos da mão de obra, em favor dos interesses do empresariado. 
tanto, retomamos os acontecimentos centrais do governo Cardoso, que levaram ao lançamento das negociações Mercosul-UE.

\section{As negociações Mercosul-UE nos governos Fernando Henrique Cardoso e Lula}

Na esteira da liberalização política e da abertura econômica iniciadas no país no final da década de 1980, a política externa brasileira e a agenda de negociação de tratados de livre-comércio e de integração econômica passam por inflexões importantes que são informadas tanto por essas injunções e condicionantes domésticos, quanto por um cenário internacional cada vez mais multifacetado e multidimensional que requer a busca por “peças” e “jogadas” adaptadas às contingências de cada arena política18 (NYE, 2002). Diante disso, firmou-se uma orientação política que ensejava maximizar as chances de obter concessões e benefícios econômicos propiciados por diferentes arenas e frentes de negociação comercial.

É possível apontar três frentes nas quais o país se engajava: (i) multilateral; (ii) intrarregional e (iii) interregional. Segundo Oliveira e Milani (2012), a prioridade dada ao multilateralismo se combinava com um regionalismo em dois tempos: um voltado à ampliação e aprofundamento da integração regional na América do Sul e outro de negociação de acordos comerciais fora da região. Essa agenda comercial dilatada trazia consigo a possibilidade de barganha entre as diferentes frentes e se somava aos esforços de atração de investimentos estrangeiros e de integração mais competitiva nas correntes globais de comércio.

Essa ênfase pró-liberalização adquiriu maior consistência e passou a ser um item-chave do programa de governo de uma ampla coalizão político-partidária nos governos Cardoso (1995-2002). A subida de FHC ao poder coincidiu com o estabelecimento da OMC e também com a iniciativa estadunidense de lançar as negociações para criação da Alca que, entre seus propósitos, pretendia ampliar

18 Segundo Nye (2002), o sistema internacional do pós-Guerra Fria pode ser entendido por meio do emprego da metáfora do xadrez tridimensional: no primeiro tabuleiro, prevalece a unipolaridade e o poderio militar dos Estados Unidos; no segundo, no qual se desenrolam as relações econômicas, observa-se uma distribuição multipolar do poder; no último, que abarca as questões transnacionais, o poder encontra-se difuso entre atores estatais e não estatais. 
o alcance dos processos de integração que vinham sendo firmados em todo o continente, como o Mercosul (1991) e o $\operatorname{NAFTA}^{19}(1994)$. A proposta dos Estados Unidos previa ampla abertura dos mercados dos países do continente às exportações industriais, ofertando, em contrapartida, o acesso ainda limitado ao seu mercado agrícola por parte dos exportadores dos países vizinhos.

O Mercosul, recém dotado de personalidade jurídica, assinou o Acordo Quadro de Cooperação Interregional com a UE em 1995 e assentou as bases para as negociações de formação de uma área de livre-comércio entre os blocos, oficializadas a partir de 1999. O entrelaçamento dessas várias frentes de negociação também estava em perspectiva pelo lado dos europeus, já que anteviam uma provável perda de participação de suas empresas do outro lado do Atlântico com o avanço da ALCA, tal como já haviam experimentado em suas relações com o México, quando o mesmo se juntou ao NAFTA (SANTOS, 2018).

Além disso, os interesses da UE se voltavam especialmente para os países latino-americanos e, particularmente, para o Cone Sul, pois despontavam como receptores de investimentos externos direcionados à modernização tecnológica de suas plantas industriais e a grandes projetos de infraestrutura. Cumpre destacar que, em larga medida, esses objetivos convergiam com as prioridades então perseguidas pelos países do Mercosul. Entretanto, desde esses primórdios, a questão da liberalização do comércio agrícola se colocava como pauta sensível para ambas as partes, contrapondo demandas predominantemente ofensivas do lado do Mercosul e demandas mormente defensivas do bloco europeu.

A importância dos mercados europeus para os países do Cone Sul é notável. O Brasil, por exemplo, manteve com os membros da UE fluxos comerciais da ordem de 61,9 bilhões de euros em 2010, o equivalente a $21,3 \%$ de toda a corrente de comércio exterior do país. Por outro lado, o bloco europeu é o maior investidor estrangeiro no país, com inversões de capital que alcançaram 131,9 bilhões de euros também em 2010, ou 49,2\% do total (OLIVEIRA, 2012). No geral, é possível apontar um nível não trivial de complementaridade entre as pautas de exportação e importação do Brasil em relação àquelas dos países da UE, embora a lista de produtos brasileiros seja bem menos diversificada - com o predomínio de commodities agrícolas e minerais.

19 Acrônimo em inglês para o Tratado Norte-Americano de Livre Comércio formado por Estados Unidos, Canadá e México. 
Gráfico 3 - Evolução do Comércio Brasil-UE - 1985-2003

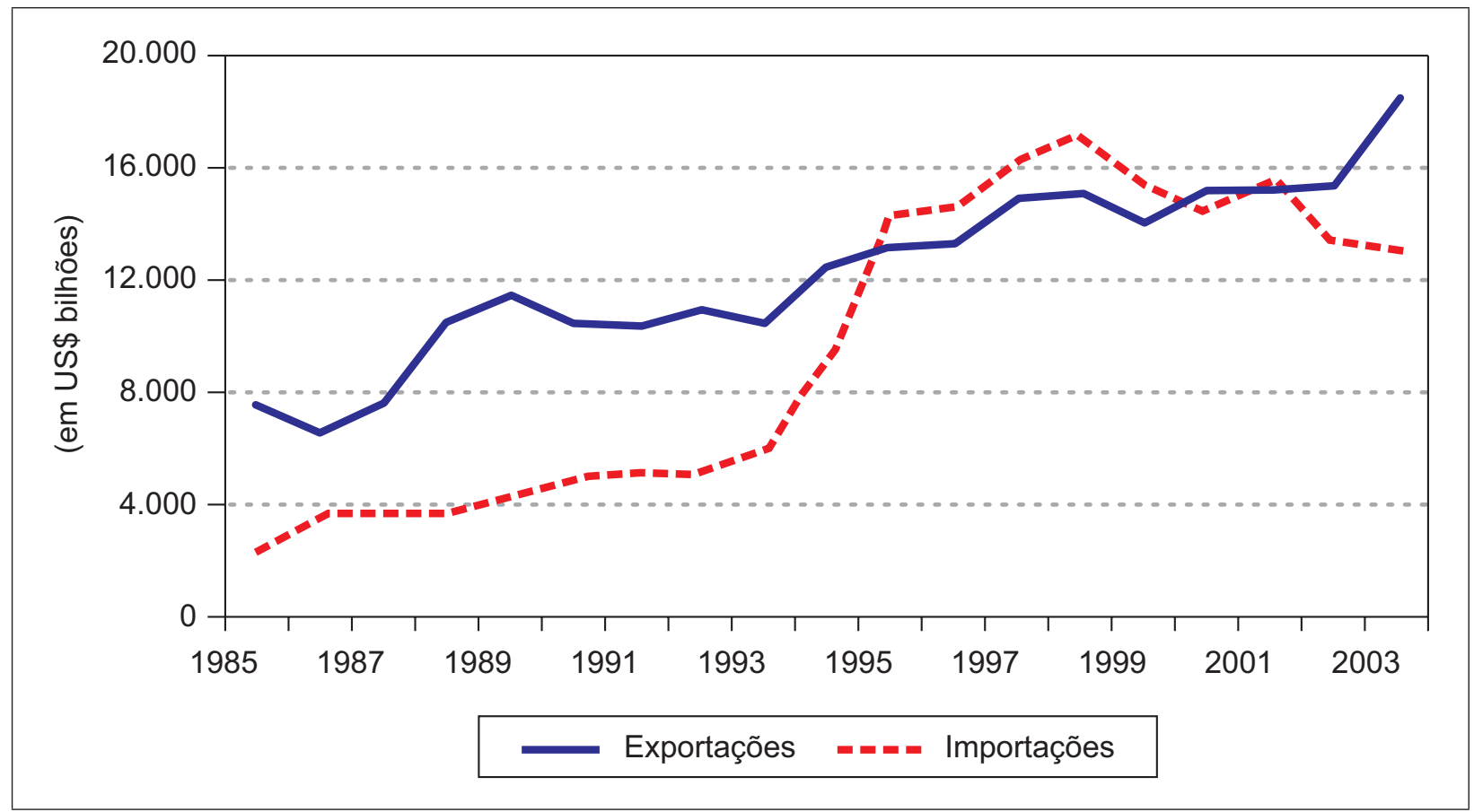

Fonte: extraído de: KUME et. al., 2004.

Como se vê no gráfico acima, o período que se seguiu à assinatura do Acordo Quadro de Cooperação Interregional entre Mercosul e UE coincidiu com uma forte alta das exportações europeias para o Brasil, enquanto as exportações brasileiras cresceram a taxas menores, porém mais constantes - inclusive após a crise cambial de 1998, quando as vendas europeias ao país começam a retrair e passaram a enfrentar maior concorrência dos produtos chineses. Em todo caso, as negociações para o Acordo de Associação foram lançadas oficialmente em 1999, por ocasião da Cúpula União Europeia-América Latina e Caribe (EU-LAC, sigla em inglês), realizada no Rio de Janeiro.

Cabe observar que questões econômicas e comerciais dividiam espaço com a intenção da UE de promover seu modelo de regionalismo para o mundo, o que ensejava a proposição de um tipo específico de "tratado guarda-chuva”: o Acordo de Associação. Esse instrumento contempla o estabelecimento de cooperação em muitos setores e usualmente prevê protocolos de harmonização políticoinstitucionais e lista as áreas-chave que contarão com ajuda (financeira, legal, organizacional) da UE. Não por acaso, o passo que geralmente antecede a adesão de um novo membro ao bloco europeu envolve o estabelecimento de um Acordo de Associação, tal como ocorreu recentemente com Romênia, Hungria, Bulgária e Croácia (TOMAZINI, 2012). 
Por certo, essa abordagem representou um fator de atratividade para a troca de ofertas entre Mercosul e UE. Os presidentes do Mercosul manifestavam um aparente consenso quanto à conveniência do acordo e, no caso específico do Brasil, as negociações com a UE eram vistas como mais palatáveis do que o projeto ALCA, sendo essa a percepção compartilhada, inclusive, pelo corpo diplomático (ONUKI, 2012). Na realidade, a posição inicial do governo FHC em relação à ALCA era predominantemente de oposição e não-engajamento, seguida por uma aparente apatia do empresariado e da sociedade civil, às voltas com os efeitos deletérios da estabilização econômica levada a cabo no país (PIZETTA, 2005).

Mas esse quadro vai progressivamente se alterando à medida em que se tornou evidente que a ALCA era "para valer” e que os custos e riscos de sua concretização seriam altos, principalmente por abranger os Estados Unidos, maior potência econômica mundial. De tal sorte que foi-se criando um conjunto de novos arranjos institucionais como o Fórum Empresarial das Américas, a Coalizão Empresarial Brasileira (CEB) e, acima de tudo, um espaço público-privado de coordenação política: a Seção Nacional de Coordenação de Assuntos Relacionados à Área de Livre Comércio das Américas (SENALCA).

Nesse sentido, as negociações da ALCA não representaram apenas um contrapeso e instrumento de barganha vis-à-vis as tratativas Mercosul-UE. Elas tiveram um papel essencial para o aprendizado político e para a concertação de interesses entre agências de governo e o setor privado no tocante às negociações comerciais internacionais. A CEB, embora mais atuante no projeto ALCA, acabou sendo importante em ambas as frentes. O modus operandi do Fórum Empresarial das Américas, por seu turno, também inspirou a formatação do Fórum Empresarial Mercosul-União Europeia. Por último, o traço mais claro dessa imbricação talvez seja a replicação do modelo SENALCA com a criação, em 2001, da Seção Nacional de Coordenação dos Assuntos Relacionados à Associação Inter-Regional MercosulUnião Europeia (SENEUROPA).

Porém, esse conjunto de convergências tinha limites muito claros no que tange aos interesses em jogo e às perspectivas de ganhos frente a cada uma das negociações. Em 2001, o governo brasileiro encomendou um estudo à Fundação Getúlio Vargas para avaliar os efeitos de um ou de outro acordo sobre os diferentes setores da economia e o potencial de crescimento do PIB. Como resultado, constatou-se que o país - e seus parceiros do Mercosul idem - teria ganhos mais imediatos e consistentes, em termos agregados, optando pela integração com a UE em contraposição à ALCA (ARAÚJO, 2018). 
Parte da explicação para isso reside no fato de que o agronegócio brasileiro se defronta com barreiras excepcionalmente altas na Europa para os principais produtos de sua pauta exportadora, com destaque para os complexos de proteína animal. Mas, mesmo assim, o Brasil é, desde o ano 2000, o principal exportador de produtos agrícolas para os países daquele continente. Portanto, "o crescimento maior da economia brasileira no caso de um acordo com a UE se explica pela resposta imediata que o agronegócio brasileiro daria no caso de a Europa de fato derrubar o muro protecionista que ergueu em torno de seus agricultores" (ARAÚJO, 2018, p. 318).

No caso ALCA, embora a perspectiva de ganhos concentrados no setor industrial exercesse grande atratividade, as tarifas de importação dos EUA (o maior mercado da ALCA) já são, no geral, baixas. Ademais, o Brasil estava longe de ser um dos principais exportadores de manufaturados para o mercado estadunidense e, num eventual desfecho do acordo hemisférico, havia o risco de perdermos uma parcela importante de mercados de produtos industriais nos países vizinhos da América do Sul. Ciente disso, o governo brasileiro insistiu numa estratégia pragmática de seguir negociando em ambas as frentes, no intuito de maximizar as concessões e vantagens potenciais e, vale dizer, sempre em estreita interlocução com representantes do setor privado.

Com efeito, o projeto ALCA já vinha dando sinais de impasse com a recusa dos EUA em liberalizar o acesso ao seu mercado de produtos agrícolas, ao mesmo tempo em que os interesses do agronegócio brasileiro adquiriam cada vez mais espaço nos fóruns empresariais. Segundo Pizzeta (2005), as disputas internas sobre os posicionamentos da Coalizão Empresarial Brasileira (CEB), transmitidos ao governo, se acirraram a partir do Fórum Empresarial das Américas de Toronto, em 1999, "quando os interesses do setor agrícola passaram a ganhar mais voz dentro da Coalizão" (PIZZETA, 2005, p. 86 ).

Contudo, esse crescente peso dos interesses ofensivos dos atores do agronegócio não se restringia à CEB. A mobilização política dos diversos segmentos agrícolas e agroindustriais em prol da liberalização comercial já vinha adquirindo consistência desde o limiar da era FHC. Em 1996, o Ministério da Agricultura e as principais entidades de representação da agricultura empresarial lançaram o Fórum Nacional da Agricultura (FNA), no intuito de formular uma agenda estratégica para o setor, que ficaria conhecida como "As Dez Bandeiras do Agronegócio". Tratado como transversal, o tema do comércio internacional de produtos agrícolas fez jus à estruturação de um subgrupo dentro do FNA, cuja tônica das discussões (que 
duraram 18 meses) e contribuições ao documento final versavam, não apenas sobre a necessidade de elevar a participação brasileira nas correntes globais de comércio agrícola, mas, também, recobravam maior participação de representantes do agronegócio nas diversas instâncias de formulação e implementação da política comercial.

Em paralelo à CEB, essa resolução foi igualmente determinante na criação do Fórum Permanente de Negociações Agrícolas Internacionais em 1999, num esforço conjunto de $\mathrm{CNA}^{20}, \mathrm{OCB}^{21}$ e $\mathrm{ABAG}^{22}$ e no estabelecimento do Instituto de Estudos do Comércio e Negociações Internacionais (ICONE), em 2003. Este foi o primeiro think tank inteiramente voltado à produção e disseminação de informações sobre comércio internacional de produtos agrícolas, além de interlocutor privilegiado do Ministério da Agricultura e do Itamaraty nessa seara. Em suma, observa-se a predominância de "uma estratégia pragmática por parte da agricultura, buscando atuar em diferentes espaços de poder de modo a maximizar os seus interesses" (CARVALHO, 2003, p. 372).

Esse estado de coisas se provou componente importante para a sobrevida das negociações Mercosul-UE, mesmo após o malogro da ALCA. A perspectiva de ganhos concentrados em commodities agrícolas representou um desincentivo para a mobilização do empresariado industrial o que, por sua vez, contribuiu para que as posições da CEB encaminhadas ao Itamaraty refletissem uma proeminência dos interesses do setor agrícola. Esse novo equilíbrio das posições alcançou notoriedade no debate público em 2004, quando o empresariado da indústria chegou a criticar o fato de que a Coalizão estaria se tornando uma organização excessivamente vinculada aos interesses do setor agrícola e propôs a criação de uma Coalizão somente da indústria (PIZZETA, 2005).

Além do protagonismo do agronegócio, outros elementos concorriam para o prosseguimento das tratativas Mercosul-UE, como o envolvimento de representantes da Comissão Parlamentar Conjuntura e do Fórum Consultivo Econômico e Social do Mercosul tanto no capítulo propriamente comercial do acordo e, particularmente, nos itens políticos e de cooperação. Ao fim e ao cabo, as negociações entre os blocos entraram em compasso de espera a partir de 2004 por conta de, entre outras coisas, mudanças nas coalizões de governo e, consequentemente, nas políticas

20 Confederação da Agricultura e Pecuária do Brasil.

21 Organização das Cooperativas do Brasil.

22 Associação Brasileira do Agronegócio. 
externas dos países do Mercosul, que passaram a priorizar o estabelecimento de parcerias com países do Sul Global. Tal orientação se manifestaria, por exemplo, nos novos acordos extrarregionais do bloco.

Quadro 1 - Acordos preferenciais de comércio extrarregionais do Mercosul

\begin{tabular}{|l|l|l|}
\hline Acordo & Assinado em: & Em vigor desde: \\
\hline Mercosul-Palestina & Dezembro de 2011 & - \\
Mercosul-Egito & Agosto de 2010 & Setembro de 2017 \\
Mercosul-SACU23 & Dezembro de 2008 & Abril de 2016 \\
Mercosul-Israel & Dezembro de 2007 & Abril de 2010 \\
Mercosul-Cuba & Julho de 2006 & Julho de 2007 \\
Mercosul-Índia & Março de 2005 & Junho de 2009 \\
\hline
\end{tabular}

Fonte: BRASIL (2018).

Todavia, mesmo após o congelamento oficial das negociações Mercosul-UE, alguns avanços na aproximação entre os dois blocos podem ser identificados por meio da continuidade das plenárias do Fórum Empresarial Mercosul-União Europeia, sendo uma sediada em Buenos Aires, em 2004, e outra em Lisboa, em 2007. Chama atenção o fato de que, nessas duas ocasiões, a representação brasileira era predominantemente composta por empresários ligados ao agronegócio (ONUKI, 2012). A despeito do hiato formal das negociações, a UE implementou, ainda em 2007, sua Parceria Estratégica ${ }^{24}$ com o Brasil, sinalizando para a manutenção do interesse do bloco em seguir estreitando seus laços com o Cone Sul — ou, pelo menos, com parte dele.

Feita a discussão pertinente à coordenação dos interesses do agronegócio, na próxima seção nos voltamos para a análise das negociações Mercosul-UE durante os governos Rousseff e Temer, buscando evidenciar como o ascendente protagonismo adquirido pelo agronegócio conseguiu ser decisivo na formação da posição negociadora do Brasil na fase de retomada das tratativas Mercosul-UE.

23 Sigla em inglês para a União Aduaneira da África Austral, composta por África do Sul, Botswana, Lesoto, Suazilândia e Namíbia.

24 Instrumento que prevê um relacionamento bilateral de mais alto nível, abarcado a realização de cúpulas e consultas periódicas e a consecução de um Plano de Ação Conjunta em múltiplas áreas. Em razão desse estatuto “especial”, são poucos os países com os quais a UE firmou esse tipo de parceria: Estados Unidos, Canadá e Japão, BRICS e México (TOMAZINI, 2012). 


\section{As negociações Mercosul-União Europeia nos anos recentes: os interesses e a posição negociadora do Brasil}

A política externa do governo Dilma foi marcada tanto por continuidades como por descontinuidades em relação ao governo Lula. Os mesmos objetivos foram mantidos (expansão dos mercados para produtos brasileiros, elevação na qualidade da participação do país na gestão de conflitos internacionais), assim como a maneira de conquistá-los (participação em coalizões de geometria variável, com ênfase para as relações sul-sul e participação em fóruns multilaterais). Porém, houve mudanças no contexto internacional, que não permitiriam grande sucesso em suas ações como o presidente anterior conquistou. Além disso, observou-se menor engajamento pessoal da própria presidente e do governo em relação à agenda internacional, ao mesmo tempo em que o Itamaraty, assim como os embaixadores e ministros, ganharam pouca autonomia, menos prestígio e importância dentro do governo (SARAIVA, 2016).

Dessa forma, a política externa sob Dilma foi taxada como "reativa", marcada por reações de curto prazo às situações que foram se apresentando no decorrer do governo. No plano doméstico, a marginalização do Itamaraty, junto à falta de engajamento pessoal da presidente, resultou em ausência de agenda externa que pudesse planejar a maior inserção do Brasil no plano internacional.

Nesse plano, a crise financeira global de 2008 se estendeu pelos anos subsequentes, com efeitos negativos sobre os países da América do Sul. O fim do boom das commodities afetou as exportações para parceiros externos. A queda do nível de atividade econômica, ademais, levou à redução do comércio entre os países sul-americanos. O contexto internacional negativo desembocou em mudanças na maneira de fazer comércio, inclusive por parte dos países sul-americanos. Como consequência, o cenário internacional passou a se mostrar mais defensivo: questões comerciais não avançaram no âmbito multilateral e os países desenvolvidos (principalmente a UE) passaram a apostar em acordos bilaterais (KEGEL; AMAL, 2013).

Quando teve início o segundo mandato de Rousseff, a Europa e os Estados Unidos ainda se recuperavam da crise, o que restringiu o espaço, aberto em seu ápice, para o crescimento do poder de barganha dos países em desenvolvimento nos fóruns multilaterais. Houve também pequena desaceleração do crescimento chinês, o que resultou em uma diminuição, ainda que moderada, do comércio entre Brasil e China, país que havia se convertido no principal destino das exportações brasileiras (BIANCO, 2017; KEGEL; AMAL, 2013). 
No que diz respeito às negociações Mercosul-UE, Rousseff não obteve muitos avanços no primeiro mandato. Segundo Saraiva (2016), houve uma movimentação interna a favor de negociações diretas entre Brasil e UE, sem a inclusão do restante do bloco sul-americano. Para esta corrente, os outros membros do bloco - em particular a Argentina - estariam "limitando" as oportunidades brasileiras. Nesse sentido, uma parceria com a UE era vista como positiva e de interesse de alguns segmentos do país. Entretanto, apesar da busca pelo fechamento de um acordo com o bloco europeu ser bem vista pelo governo brasileiro, havia divergências entre os setores industrial e agrícola. Não era apenas na Argentina, portanto, onde havia interesses defensivos que impunham empecilhos ao fechamento do acordo, tanto em 2004 como em 2013: essas resistências também existiam no Brasil, embora com um nível de flexibilidade maior que no país vizinho (SANTOS, 2018).

Na primeira década dos anos 2000, prevaleceu uma clara divisão entre os dois setores: o agronegócio era mais favorável à maior liberalização e ao tratamento da redução dos subsídios agrícolas no âmbito interregional, ao passo que o setor industrial dispunha de uma posição mais defensiva, sustentando que a negociação da redução dos subsídios fosse feita preferencialmente no âmbito da OMC. Desta forma, o empresariado industrial antecipava que mudanças prejudiciais aos seus interesses seriam minimizadas em arenas multilaterais. Apenas após o fracasso da Rodada Doha que os dois setores começam a convergir de forma favorável à abertura comercial, defendendo a inserção do Brasil nas cadeias globais de valor. Ainda assim, o empresariado industrial adotou um tom cauteloso em relação a essa abertura, reivindicando que fosse feita de forma gradual. Paralelamente, foi retomado o discurso - presente já na década de 1990 durante a abertura comercial - de que havia necessidade de diminuição do protecionismo para que o setor ganhasse mais competitividade no plano internacional. Visto que o governo Dilma também tinha como foco proteger as indústrias sensíveis no âmbito do seu ensaio desenvolvimentista, muitas vezes um posicionamento mais defensivo deste setor também foi levado à mesa de negociação, apesar do grande peso que o setor agrícola dispunha no país (SANTOS, 2018).

Vale destacar que a retomada das negociações Mercosul-UE antecede o governo Rousseff. Elas foram reativadas em 2010, durante a IV Cúpula Birregional entre UE e América Latina, quando se definiu o ano de 2013 como limite para a apresentação de propostas das duas partes. Apesar do novo engajamento nas negociações com a UE, o Mercosul enfrentava dificuldades internas, relacionadas ao estabelecimento de união aduaneira somente “imperfeita”. De 2010 a 2012, as 
discussões não chegaram a progressos concretos no que se diz respeito às categorias principais de negociação de redução de barreiras tarifárias e não tarifárias. Como consequência, não obstante as pressões da UE para que os blocos apresentassem suas ofertas e se comprometessem a finalizar o acordo no tempo estipulado, as negociações passaram por mais um período de congelamento entre 2014 e 2015, caracterizado pela adoção de medidas protecionistas tanto por parte do Brasil como da Argentina (SANTOS, 2018).

As negociações foram retomadas em 2016, em resposta a uma mudança importante no contexto internacional: a eleição de Trump nos Estados Unidos, que passou a adotar uma política comercial de cunho protecionista. No entanto, no mesmo ano, Dilma enfrentou uma grave crise política que culminou na sua derrubada, em processo de impeachment controverso que alçou Temer ao poder. A mudança de governo, porém, não modificou a estratégia brasileira no que diz respeito às negociações Mercosul-UE. Pelo contrário, o foco europeu em fechar acordos bilaterais preferenciais foi encarado como uma janela de oportunidade para a aceleração das tratativas (KEGEL; AMAL, 2013; MARIANO, 2017).

Serra e Nunes, ministros das Relações Exteriores durante o governo Temer, estabeleceram como foco da política externa brasileira a conclusão de acordos bilaterais e a aproximação com o Norte global. Serra, em particular, defendeu a necessidade de o Mercosul retomar um enfoque estritamente comercial, colocando-se ainda contra a presença da Venezuela no grupo (MARIANO, 2017; SANTOS, 2018). Para promoção das negociações comerciais, foi estabelecida a coordenação entre instâncias governamentais - Itamaraty, Ministério da Indústria, Comércio Exterior e Serviços (MDIC) e a Câmara de Comércio Exterior (CAMEX) e o empresariado, na busca por "acelerar o processo de negociações comerciais para abrir mercados" (SANTOS, 2018, p. 88).

O governo brasileiro revelou-se bastante otimista no processo de fechamento do acordo entre os dois blocos. Durante o Encontro Nacional de Comércio Exterior (ENAEX), em 2017, Temer ressaltou a importância do acordo, defendendo ainda que as reformas estruturais aprovadas em seu governo eram essenciais para o fechamento do acordo. No mesmo evento, Ronaldo Costa Filho, diretor do departamento de Negociações Comerciais Extrarregionais do Ministério das Relações Exteriores (MRE), apontou que a retomada das negociações bilaterais se colocava como respostas à paralisia da OMC, e ainda, ressaltou o desafio agrícola na finalização do acordo. Podemos observar o apoio do governo ao acordo também na Declaração Conjunta por ocasião da Visita do Presidente do 
Governo do Reino da Espanha ao Brasil em 2017, na qual ambos apontaram a importância do acordo Mercosul-UE e a disposição de cooperar nas negociações (BRASIL, 2017; SANTOS, 2018).

Entre 2016 a 2018, as negociações geraram avanços e fechamento de alguns capítulos, porém ainda permaneceram divergências, que deveriam ser superadas para que o pré-acordo pudesse ser fechado dentro do prazo previsto, em dezembro de 2017. As principais diferenças giravam em torno das questões relativas à carne bovina e ao etanol. Para os países do Mercosul, a proposta apresentada pela UE no final de 2017 deixava muito a desejar. Diante do impasse, o Mercosul ampliou a proposta apresentada, estabelecendo a liberalização de $90 \%$ do comércio (a anterior previa uma liberalização de $54 \%$ ), levando a UE a melhorar sua proposta no que tange às cotas de algodão, etanol e carne bovina. No entanto, em 2018, o bloco europeu voltou atrás e se mostrou "impossibilitado" de oferecer uma contrapartida à altura do esperado pelos países do Mercosul em temas agrícolas (BIANCO, 2017; MOREIRA, 2017f).

Apesar da centralidade da questão agrícola, este não era, naturalmente, o único setor de interesse do Brasil no âmbito das negociações Mercosul-UE. No quadro abaixo, especificamos estes temas, sendo possível identificar que aqueles considerados mais importantes pelos negociadores brasileiros são propriedade intelectual, regime de drawback (regras de origem), compras governamentais e produtos agrícolas.

\section{Quadro 2 - Interesses brasileiros nas negociações Mercosul-UE}

\begin{tabular}{|l|l|}
\hline \multicolumn{2}{|c|}{ Principais pontos para o fechamento do acordo Mercosul-UE } \\
\hline Tema & Posicionamento \\
\hline Propriedade Intelectual & Interesse ofensivo da UE \\
Regras de Origem - manufaturados & Interesse ofensivo do Mercosul \\
Regras de Origem -drawback & Interesse ofensivo do Mercosul \\
Barreiras técnicas ao comércio & Interesse defensivo do Mercosul \\
Compras Governamentais & Interesse ofensivo da UE \\
Medidas Sanitárias e Fitossanitárias & Interesse ofensivo da UE \\
Produtos Agrícolas & Interesse ofensivo do Mercosul \\
Produtos Industriais & Interesse ofensivo da UE \\
\hline
\end{tabular}

Fonte: extraído de FERREIRA, F. (2018).

No que se refere à propriedade intelectual, houve flexibilização do Mercosul, que aceitou uma definição de regras de solução de conflito envolvendo questões 
geográficas de regras de origem. Porém, em relação ao tema de patentes de medicamentos importantes para as políticas de saúde pública, considerado item inegociável para os países do Mercosul, o bloco europeu não demonstrou a mesma flexibilidade, com interesse de que seguissem regras da OMC plus ${ }^{25}$ e $\mathrm{OMPI}^{26}$ (MOREIRA, 2017d).

O regime de drawback aparece como ponto de interesse defensivo da UE, que quer a eliminação do tema no acordo, pois argumenta que já tem tarifas baixas e acordos de livre comércio com muitos outros países. Para os europeus, a inclusão deste tema no acordo acabaria por permitir a livre entrada de peças e produtos oriundos, ainda que parcialmente, de países com os quais a UE não tem acordo de livre comércio 27 (RITNNER, 2017).

Em 2017, a UE endureceu sua posição no que diz respeito à abertura dos mercados mercosulinos aos produtos industrializados, requerendo a inclusão de compromissos em linha com o Acordo de Compras Governamentais da OMC, do qual nenhum país membro do Mercosul faz parte. Inicialmente, o Mercosul apresentou ressalvas em relação aos interesses da UE nesse tema, mas em dezembro de 2017 aceitou que as licitações no nível federal ou nacional passassem a incluir a participação de empresas da UE instaladas na Argentina, Brasil, Paraguai e Uruguai (SANTOS, 2018; RITNNER, 2018b; MERCOSUL..., 2017).

O relaxamento da posição do Mercosul no que tange aos temas associados a interesses caros à indústria, como propriedade intelectual e compras governamentais, não veio acompanhado de uma oferta expressiva da UE sobre temas agrícolas. Conforme afirmamos acima, a oferta europeia para o setor agrícola trouxe um nível de cotas aquém do esperado pelos governos sul-americanos, especialmente no que diz respeito à carne bovina e ao etanol. Diante do impasse, o empresariado brasileiro se dividiu: enquanto o agronegócio insistia na defesa da abertura dos mercados europeus aos seus produtos, o empresariado industrial - em particular a Confederação Nacional da Indústria (CNI) - se posicionou a favor do fechamento do acordo, visando garantir os ganhos associados à inclusão do regime de drawback no texto final. Para representantes da indústria, caso o governo brasileiro e seus parceiros no Mercosul desistissem da proposta apresentada, dificilmente a UE estaria

25 OMC plus é "a negociação de regras que ultrapassam as regras da OMC, em temas já do âmbito da OMC." (THORSTENSEN; BADIN; MÜLLER; ELEOTÉRIO,2014, p.1)

26 Organização Mundial da Propriedade Intelectual.

$2723 \%$ das exportações brasileiras para os europeus utilizam drawback, e a maioria dos itens vem da China, país com o qual a UE ainda não possui acordo preferencial (RITNNER, 2017). 
disposta a voltar a negociar no futuro (RITNNER; ZAIA, 2017; MOREIRA, 2017e)

Ainda sobre as ofertas agrícolas, na rodada de negociações em Buenos Aires, em dezembro de 2017, mês previsto para o lançamento de um pré-acordo, a UE mostrou que aumentaria a cota de importação de carne de frango e de açúcar do Mercosul. Na imprensa, comentava-se que o bloco europeu aumentaria a cobertura birregional de $90 \%$ para $92 \%$ do comércio ${ }^{28}$. Em resposta, o Mercosul se "comprometeu a eliminar tarifas em $90 \%$ das exportações europeias para o mercado do cone sul”, porcentagem pedida pela UE desde o início das negociações. Segundo a proposta, primeiramente, seria feita uma redução de $60 \%$, em 10 anos, e depois de 90\%, em 15 anos (MOREIRA, 2017a; 2017b;2017c, 2017d, 2017f ).

Nesse contexto, a CNI se posicionou de maneira positiva à rodada de negociação do final de 2017, afirmando que já havia concessões aos pontos de interesse brasileiro nas áreas agrícola e industrial. Para a entidade, com o fechamento do acordo, o Brasil se colocaria no curto prazo entre os grandes players no comércio internacional, podendo "triplicar o acesso a novos mercados para os bens brasileiros." No entanto, apesar do otimismo do empresariado, o Ministro da Indústria, Comércio Exterior e Serviços criticou a lentidão do processo de negociação por parte da UE (NOVA..., 2017). Os europeus relutavam em incluir cotas mais abrangentes para etanol e carne bovina, além de considerarem que a questão do regime de drawback deveria passar por novas discussões (MOREIRA, 2017a; 2017b; 2017d; 2018a; 2018b; 2018c; RITNNER, 2018a).

Em 2018, novas rodadas de negociação foram levadas a cabo. Em junho daquele ano, o Mercosul apresentou uma proposta de flexibilização da restrição da entrada de carros europeus nos mercados dos países-membros, ofertando uma cota com tarifas 50\% inferiores às praticadas então (MOREIRA, 2018d). Apesar do novo relaxamento na posição negociadora dos países sul-americanos, o impasse permaneceu: o bloco europeu se manteve pouco flexível na abertura do seu mercado de bens agropecuários (FERREIRA, A. 2018). Desta forma, o otimismo inicial do governo Temer em relação às negociações não se traduziu no fechamento do acordo, ao menos durante o seu mandato. $\mathrm{O}$ acordo foi fechado no ano seguinte, durante o governo Bolsonaro, sem que tenha ocorrido, entretanto, nova troca de ofertas (ACORDO... 2019). Para entrar em vigor, o acordo ainda precisa ser ratificado pelo Parlamento Europeu e pelos legislativos de cada um dos países que compõem os dois blocos.

$2870 \%$ do comércio entre os dois blocos já possui tarifa zero. 


\section{Conclusão}

As negociações Mercosul-UE ganharam novo impulso durante os governos Dilma Rousseff e Michel Temer. A eleição de Maurício Macri, de centro-direita, na Argentina apontava para uma convergência programática em relação ao governo Temer, com a promessa de que as negociações com o bloco europeu finalmente chegariam a termo, após duas décadas. No entanto, apesar da flexibilização do Brasil e de seus parceiros no que diz respeito à abertura dos seus mercados de bens industrializados - incluindo alguns dos chamados novos temas do comércio internacional, como propriedade intelectual e compras governamentais a oferta para maior acesso ao mercado agropecuário europeu permaneceu aquém do esperado, de forma que o governo Temer chegou ao fim sem que lograsse concluir as negociações. A assinatura do acordo ocorreu apenas em 2019, já durante o governo Bolsonaro.

Neste artigo, analisamos o impasse a partir da perspectiva da formação da posição negociadora do Brasil2 ${ }^{29}$. Argumentamos que mudanças estruturais relacionadas ao perfil da economia brasileira, com sua progressiva desindustrialização e a reprimarização da pauta exportadora, influenciam a formatação da agenda de negociação do país. Essa mudança, porém, não ocorre de forma automática, respondendo também à maior capacidade de coordenação da ação coletiva do agronegócio nos temas caros à política comercial, inclusive no que diz respeito às negociações Mercosul-UE.

Mapeamos esta mudança levando em consideração, ademais, as novas configurações no contexto internacional, marcado pela animosidade crescente em relação às negociações multilaterais e pela adoção de práticas protecionistas, sobretudo, mas não exclusivamente, nos Estados Unidos a partir da eleição de Trump. As alterações na conjuntura global acabaram por impulsionar iniciativas bilaterais, abrindo uma janela de oportunidade para a retomada das negociações Mercosul-UE.

Nesse sentido, argumentamos que a permanência destas negociações como tema prioritário na agenda de diferentes governos no Brasil pode ser compreendida à luz de mudanças mais fundamentais na economia política doméstica e internacional. Embora este artigo apresente os resultados de uma pesquisa que teve como escopo os governos Dilma e Temer, esperamos testar nossa hipótese em pesquisas

29 Naturalmente, os interesses dos demais países do Mercosul e a formação das preferências da UE também importam para uma visão global das negociações, mas ultrapassam o escopo deste artigo. 
vindouras, que se debrucem sobre as tratativas que levaram à assinatura do acordo nos primeiros meses do governo Bolsonaro e as negociações no nível parlamentar voltadas para a sua eventual ratificação.

\section{Referências}

ACORDO com União Europeia tira Mercosul de isolamento. G1, Rio de Janeiro, 28 jun. 2019. Disponível em: < https://g1.globo.com/economia/noticia/2019/06/28/acordocom-uniao-europeia-tira-mercosul-de-isolamento-entenda.ghtml > . Acesso em: 12 setembro 2019.

ARAÚJO, Ricardo Guerra. O jogo estratégico nas negociações Mercosul-União Europeia. Brasília: FUNAG, 2018.

BANCO MUNDIAL. DataBank. 2018. Disponível em: < https://databank.worldbank.org/ data/home.aspx > . Acesso em: 26 setembro 2018.

BASTOS, Pedro Paulo; HIRATUKA, Celio. A política econômica externa do governo Dilma Rousseff: comércio, cooperação e dependência. Instituto de Economia/Unicamp, 2017. (Texto para Discussão 306).

BEZERRA, Vicente Amaral. Participação de grupos empresariais em negociações comerciais: o caso das negociações entre Mercosul e União Europeia (2001-2004). Dissertação (Mestrado em Ciências Sociais). Universidade de Brasília, Brasília, 2008.

BIANCO, Carlos. Historia de una entrega: El estado actual de las negociaciones para un tratado de libre comercio entre el Mercosur y la UE. Dossier de Integración Regional, n. 1. 2017.

BRASIL. Ministério das Relações Exteriores. Declaração conjunta por ocasião da visita do Presidente do Governo do Reino da Espanha ao Brasil. Brasília, 2017 Disponível em: $<$ http://www.itamaraty.gov.br/pt-BR/notas-a-imprensa/16163-declaracao-conjuntapor-ocasiao-da-visita-do-presidente-do-governo-do-reino-da-espanha-ao-brasil-24-e25-de-abril-de-2017 > . Acesso em: 27 de novembro 2017.

BRASIL. Ministério do Desenvolvimento, Indústria e Comércio Exterior. [S.1.] Negociações internacionais: acordos dos quais o Brasil é parte. Disponível em <http//: http:// www.desenvolvimento.gov.br//sitio/interna/interna.php?area $=5 \& m e n u=405>$. Acesso em 11 março 2018.

CARNEIRO, Flavio Lyrio. Parceria Trans-Pacífico: um acordo megarregional na fronteira da regulação do comércio internacional? Brasília/Rio de Janeiro: IPEA, 2015. (Texto para Discussão 2108).

CARVALHO, Maria Izabel V. de. Estruturas domésticas e grupos de interesse: formação da posição brasileira para Seattle. Contexto Internacional, v. 25, n. 2, 2003. 
CARVALHO, Maria Izabel V. de. Condicionantes internacionais e domésticos: O Brasil e o G-20 nas negociações agrícolas da Rodada Doha. Dados, v. 53, n. 02, p. 405-445, 2010. DELGADO, Guilherme Costa. Especialização primária como limite ao desenvolvimento. Desenvolvimento em Debate, v. 01, n. 02, p. 111-125, 2010.

FERREIRA, Aloysio Nunes. As negociações Mercosul-União Europeia. O Estado de São Paulo, 28 dez. 2018. Disponível em: < http://www.itamaraty.gov.br/pt-BR/discursosartigos-e-entrevistas-categoria/ministro-das-relacoes-exteriores-artigos/19878-asnegociacoes-mercosul-uniao-europeia-o-estado-de-s-paulo-28-12-2018 > . Acesso em 30 de março 2019.

FERREIRA, Fernanda. As negociações comerciais do Brasil no século XXI: posicionamento nas negociações do acordo interregional Mercosul- UE durante 2016-2018. Rio de Janeiro: FAPERJ. 2018.

IGLÉCIAS, Wagner. O Empresariado do agronegócio no Brasil. Ação coletiva e formas de atuação política: estudo de caso das batalhas do açúcar e do algodão na Organização Mundial do Comércio. Revista de Sociologia e Política, v. 28, p. 195-217, 2007.

KEGEL, Patrícia; AMAL, Mohamed. Perspectivas das negociações entre o Mercosul e a União Europeia em um contexto de paralisia do sistema multilateral e da nova geografia econômica global. Revista de Economia Política, v. 33, n. 2, p. 341-359, abr-jun. 2013.

MARIANO, Marcelo. A crise do Brasil e a política externa do governo Temer. Anuario de Política Internacional y Política Exterior 2016-2017, p. 99-104, 2017.

MENEZES, Roberto Goulart. Soft power, o brilho da espada: o Brasil e a ordem internacional pós 11 de setembro. Mediações, v. 16, n. 02, p. 107-122, 2011.

MERCOSUL avança no comércio, mas espera acordo com a UE. Valor Econômico, São Paulo, 27 dez. 2017. Disponível em: < http://www.valor.com.br/opiniao/5238407/mercosulavanca-no-comercio-mas-espera-acordo-com-ue > . Acesso em: 26 março 2018.

MOREIRA, Assis. Acordo de livre comércio entre Mercosul e UE é adiado para 2018. Valor Econômico, São Paulo, 12 dez. 2017 (a). Disponível em: < https://www.valor.com.br/ brasil/5225841/acordo-de-livre-comercio-entre-mercosul-e-ue-e-adiado-para-2018 > . Acesso em: 16 março 2018.

MOREIRA, Assis. Mercosul aceita demanda, mas acordo com UE fica para 2018. Valor Econômico, São Paulo, 13 dez. 2017 (b). Disponível em: < http://www.valor.com.br/ internacional/5225967/mercosul-aceita-demanda-mas-acordo-com-ue-fica-para-2018 > . Acesso em: 16 março 2018.

MOREIRA, Assis. Mercosul faz concessões e aguarda reação da União Europeia. Valor Econômico, São Paulo, 12 dez. 2017 (c). Disponível em: < http://www.valor.com.br/ internacional/5225563/mercosul-faz-concessoes-e-aguarda-reacao-da-uniao-europeia > . Acesso em: 16 março 2018. 
MOREIRA, Assis. Negociação frustrada na propriedade intelectual. Valor Econômico, São Paulo, 03 out. 2017 (d). Disponível em: < http://www.valor.com.br/brasil/5142476/ negociacao-frustrada-na-propriedade-intelectual > . Acesso em: 03 outubro 2017.

MOREIRA, Assis. Oferta insuficiente põe acordo em risco, vê Mercosul. Valor Econômico, São Paulo, 02 out. 2017 (e). Disponível em: < http://www.valor.com.br/brasil/5140844/ oferta-insuficiente-poe-acordo-em-risco-ve-mercosul > . Acesso em: 04 outubro 2017. MOREIRA, Assis. UE amplia cota para compra de frango do Mercosul. Valor Econômico, São Paulo, 05 dez. 2017 (f). Disponível em: < https://www.valor.com.br/brasil/5217679/ ue-amplia-cota-para-compra-de-frango-do-mercosul > . Acesso em: 05 dezembro 2017. MOREIRA, Assis. UE acena com melhora na oferta, mas quer lácteos no acordo. Valor Econômico, São Paulo, 1 fev. 2018 (a). Disponível em: < http://www.valor.com. br/brasil/5297601/ue-acena-com-melhora-na-oferta-mas-quer-lacteos-no-acordo > . Acesso em: 28 março 2018.

MOREIRA, Assis. UE e Mercosul se reúnem em Bruxelas na busca de avanço em acordo de comércio. Valor Econômico, São Paulo, 18 jan. 2018 (b). Disponível em: < http://www.valor.com.br/brasil/5264379/ue-e-mercosul-se-reunem-em-bruxelasna-busca-de-avanco-em-acordo-de-comercio > . Acesso em: 26 março 2018

MOREIRA, Assis. União Europeia apresenta nova oferta e melhora acesso para carne do Mercosul. Valor Econômico, São Paulo, 30 jan. 2018 (c). Disponível em: < http://www.valor.com.br/brasil/5290749/unia o-europeia-apresenta-nova-ofertae-melhora-acesso-para-carne-do-mercosul > . Acesso em: 26 março 2018.

MOREIRA, Assis. Mercosul oferece cota para carro europeu com tarifa 50\% menor durante sete ano. Valor Econômico, São Paulo, 26 jun. 2018 (d). Disponível em: < https://www.valor.com.br/brasil/5618949/mercosul-oferece-cota-para-carroeuropeu-com-tarifa-50-menor-durante-sete-anos > . Acesso em: 10 março 2019.

MOROSINI, Fábio Costa; CORNETET, João Marcelo. O governo Dilma Rousseff e as negociações comerciais: retração sem desistência. Conjuntura Austral, Porto Alegre, v. 4, n.19, p. 04-10, ago./set. 2013,

NOVA Rodada Mercosul-UE em janeiro. Valor Econômico, São Paulo, 14 dez. 2017. Disponível em: < http://www.valor.com.br/internacional/5227161/nova-rodadamercosul-ue-em-janeiro > . Acesso em: 26 março 2018.

NYE, Joseph S. Paradoxo do poder americano. São Paulo: Editora UNESP, 2002.

OLIVEIRA, Ivan Tiago M.; MILANI, Carlos R. S. Atores não estatais e trade policy-making no Brasil: análise dos interesses e das estratégias da CEB e da REBRIP. Dados, v. 55, n. 2, p. 367- 401, 2012.

OLIVEIRA, Ivan Tiago M. The political economy of Brazilian trade policy: implications for Mercosur-European Union negotiations. In: Apex-Brasil (Org.). Mercosur European Union dialogue. Brasília: Apex-Brasil, 2012. p. 108 -119. 
ONUKI, Janina. Political aspects of the EU-Mercosur agreement. In: Apex-Brasil (Org.). Mercosur European Union dialogue. Brasília: Apex-Brasil, 2012. p.38-45.

PECEQUILO, Cristina Soreanu. A política externa do Brasil no século XXI: os eixos combinados de cooperação horizontal e vertical. Revista Brasileira de Política Internacional, Brasília, v. 51, n. 2, p. 36-156, dez. 2008.

PIZZETA, Diego E. A coalizão empresarial Brasileira nas negociações da Alca. Dissertação (Programa de Pós-Graduação em Relações Internacionais). Universidade Federal do Rio Grande do Sul, 2005.

RITNNER, Daniel. Acordo com UE deve ter salvaguardas à indústria por 18 anos. Valor Econômico, São Paulo, 06 mar. 2018 (a). Disponível em: < http://www.valor.com.br/ brasil/5365051/acordo-com-ue-deve-ter-salvaguardas-industria-por-18-anos > . Acesso em: 31 março 2018.

RITNNER, Daniel. Próxima Rodada ainda não fechará acordo com a UE. Valor Econômico, São Paulo, 21 fev. 2018 (b). Disponível em: < http://www.valor.com.br/brasil/5336993/ proxima-rodada-ainda-nao-fechara-acordo-com-ue > . Acesso em: 29 março 2018.

RITNNER, Daniel. Regime de ‘drawback’ cria impasse para negociação entre blocos. Valor Econômico, São Paulo, 28 nov. 2017. Disponível em: < https://www.valor.com.br/ brasil/5209109/regime-de-drawback-cria-impasse-para-negociacao-entre-blocos > . Acesso em: 05 dezembro 2017.

RITNNER, Daniel; ZAIA, Cristiano. Após aval de Juncker e Macron, UE oferece cotas agrícolas ao Mercosul. Valor Econômico, São Paulo, 04 out. 2017.. Disponível em: < http://www.valor.com.br/brasil/5144014/apos-aval-de-juncker-e-macron-ueoferece-cotas-agricolas-ao-mercosul > . Acesso em: 06 outubro 2017.

SALAMA, Pierre. Reprimarização sem industrialização, uma crise estrutural no Brasil. Argumentum, v. 08, n. 02, p. 127-139, 2016.

SANTOS, Lucas. As negociações do acordo de associação inter-regional Mercosul e União Europeia: o posicionamento dos grupos agrícolas e industriais de Argentina e Brasil. Dissertação (Programa de Pós-Graduação em Relações Internacionais) - UNESP, UNICAMP e PUC-SP, São Paulo. 2018.

SARAIVA, Miriam G. Estancamento e crise da liderança do Brasil no entorno regional. Anuario de la Integración Regional de América Latina y el Gran Caribe, v. X, p. 295-310, 2016.

SARTI, Fernando; HIRATUKA, Célio. Desempenho recente da indústria brasileira no contexto de mudanças estruturais doméstica globais. In CARNEIRO, Ricardo; BALTAR, Paulo; SARTI, Fernando (Org.). Para além da política econômica. São Paulo: UNESP Digital, 2018, Cap. 4, p. 127-170.

SINGER, André. A (falta de) base política para o ensaio desenvolvimentista. In: SINGER, André; LOUREIRO, Isabel (orgs.). As contradições do lulismo: a que ponto chegamos? São Paulo: Boitempo, 2016. p. 21-55. 
THORSTENSEN, Vera; BADIN, Michelle; MÜLLER, Carolina; ELEOTÉRIO, Belisa. Acordos preferenciais de comércio: da multiplicação de novas regras aos mega-acordos comerciais. FGV EESP - CCGI, 2014.

TOMAZINI, Rosana C. Understanding the association agreement between the EU and Mercosur: its structure, course of negotiations and the involvement of the business sector. In: Apex-Brasil (Org.). Mercosur European Union dialogue. Brasília: Apex-Brasil, 2012. p. 10-17.

TOSTES, Ana Paula. T-TIP against the wall: feasibility, resistance, and consequences for third countries. Carta Internacional, Belo Horizonte, v. 12, n. 01, p. 49-72, 2017. 